\title{
Dog and cat population dynamics in an urban area: evaluation of a birth control strategy ${ }^{1}$
}

\author{
Rita C.M. Garcia ${ }^{2 *}$, Marcos Amaku ${ }^{3}$, Alexander W. Biondo ${ }^{2}$ and Fernando Ferreira ${ }^{3}$
}

\begin{abstract}
Garcia R.C.M., Amaku M., Biondo A.W. \& Ferreira F. 2018. Dog and cat population dynamics in an urban area: evaluation of a birth control strategy. Pesquisa Veterinária Brasileira 38(3):511-518. Setor de Patologia Veterinária, Faculdade de Veterinária, Universidade Federal do Rio Grande do Sul, Av. Bento Gonçalvez 9090, Porto Alegre, RS 91540-000, Brazil. E-mail: ritamaria@ufpr.br

For canine and feline population management in an urban area, a set of well-developed strategies is required to prevent overpopulation, the abandonment of animals, and zoonosis. An understanding of the dynamics of these populations and a characterization of these populations are necessary for action planning. The proposed strategies should be monitored and evaluated so that canine and feline population management programs are properly implemented. Population management programs can be improved through evidence based adaptive management. The objective of this study was to characterize the canine and feline populations and their dynamics in an urban area and to evaluate the impact of a birth control program. Three cross-sectional census surveys and a birth control program were conducted in a neighborhood of São Paulo area with 4,275 households. The two first surveys were performed in 2005 and 2006, prior to implementation of the birth control program, and were used to characterize the canine and feline populations. The third survey was performed in 2008, eighteen months after the birth control strategy had been established. The canine population decreased from 2006 to 2008, after birth control. The mean age for the canine population was 3.36 years; $65 \%$ of the dogs were younger than 3 years of age. The mean life expectancy at birth was 3.9 years for male dogs and 5.9 years for female dogs. The mean age for the feline population was 1.66 years; $74 \%$ of the cats were 1 year of age or less. The canine and feline populations had a high mortality rate for juveniles younger than 1 year of age. There was an $8 \%$ and an $18 \%$ decrease in canine and feline birth rates, respectively, after spay or neuter intervention. There was a high animal population turnover, which was more pronounced in the feline population.
\end{abstract}

INDEX TERMS: Population management, animal control, dogs, cats, public health, spay, neuter.

\begin{abstract}
RESUMO.- [Dinâmica populacional canina e felina em área urbana: avaliação da estratégia de controle reprodutivo.] Para o manejo populacional canino e felino em área urbana, um conjunto de estratégias é necessário para evitar a superpopulação, o abandono animal e a transmissão de zoonoses. 0 entendimento da dinâmica e a caracterização
\end{abstract}

\footnotetext{
${ }^{1}$ Received on June 17, 2017.

Accepted for publication on July 5, 2017.

2 Departamento de Medicina Veterinária, Universidade Federal do Paraná (UFPR), Rua dos Funcionários 1540, Curitiba, PR 80035-050, Brazil. *Corresponding author: ritamaria@ufpr.br, ritadecassiamariagarcia@gmail.com

${ }^{3}$ Departamento de Medicina Veterinária Preventiva e Saúde Animal, Universidade de São Paulo (USP), Avenida Prof. Dr. Orlando Marques de Paiva 87, São Paulo, SP 05508 270, Brazil.
}

dessas populações são fundamentais para o planejamento das ações, monitoramento e avaliação do programa de manejo populacional e de suas estratégias. Programas de manejo populacional podem ser melhorados por meio de uma gestão adaptativa baseada em evidências. Para avaliar o impacto do controle reprodutivo de cães e gatos foram feitos três estudos transversais por meio de censos em uma área de São Paulo com 4.275 famílias. Os dois primeiros censos foram realizados em 2005 e 2006, antes do controle reprodutivo, e usado para caracterizar as populações canina e felina. 0 terceiro censo foi realizada em 2008, 18 meses após a estratégia de controle reprodutivo ter iniciado. A população canina diminuiu de 2006 a 2008, após o controle reprodutivo. A idade média para a população canina foi 3,36 anos. A expectativa de vida média ao nascer foi de 3,9 anos para os cães machos e 5,9 anos para 
as fêmeas. A idade média da população felina foi de 1,66 anos. $65 \%$ dos cães eram menores de 3 anos de idade e $74 \%$ dos gatos tinham 1 ano de idade ou menos. As populações canina e felina tiveram alta taxa de mortalidade de animais jovens. Houve uma diminuição de $8 \%$ e $18 \%$ nas taxas de natalidade canina e felina, respectivamente, após a intervenção do controle reprodutivo. Houve uma elevada renovação da população animal, mais pronunciada para a população felina.

TERMOS DE INDEXAÇÃO: Manejo populacional, controle animal, caninos, felinos, saúde pública, controle reprodutivo, castração.

\section{INTRODUCTION}

The human-animal bond can have positive or negative repercussions on the health of individuals, families and communities depending on how animals are treated and managed. This relationship can also affect animal health and welfare, traffic accidents, attacks on humans, abandoned animal as a threat to human health, environmental damages arising from wildlife depredation, and environmental contamination (Garcia et al. 2012).

The health measures used to prevent and control zoonoses and other risks posed by companion animals to humans are related to the degree of development in a given nation, the level of urbanization, social stratification as well as cultural, socioeconomic, religious and other factors (WHO 1988, WHO \& WSPA 1990).

For canine and feline population management, a set of well-developed strategies is required to prevent overpopulation and the abandonment of animals. These strategies are based on the perspective of promoting community health, human and animal welfare and maintenance of the environmental balance (Garcia et al. 2012). An understanding of the dynamics of these populations and a characterization of these populations are necessary for action planning (Dias et al. 2004, ICAM 2007). The proposed strategies should be monitored and evaluated so that canine and feline population management programs are properly implemented (Amaku et al. 2009, Garcia et al. 2012).

A birth control strategy by spay and neuter for dog population management was introduced by the World Health Organization (WHO) to reduce the birth rate and the abandonment of litters (WHO 1984, WHO \& WSPA 1990). This strategy began to be implemented with stakeholders in Taboão da Serra, SP, Brazil and evolved in Brazilian cities in the 1990s (Garcia 2009).

This study aimed to characterize canine and feline population and their dynamics in an urban area and to evaluate the impact of a canine and feline birth control program.

\section{MATERIALS AND METHODS}

This study was performed between 2005 and 2008 in Vargem Grande, a neighborhood of the municipality of São Paulo, Brazil, which encompasses 3.15 square kilometers with 4,275 households and 16,946 inhabitants ${ }^{4}$. In determining the study location, three factors were considered: the need for population management actions for dogs and cats; the isolated characteristics of the area with low interference with respect to dog and cat migration; and established partnerships between non-governmental

\footnotetext{
${ }^{4}$ IBGE census, 2000.
}

organizations (NGOs), academia, the community and public sectors (since 2004).

Three cross-sectional studies were performed using census surveys. Two of the studies were performed in 2005 (between September and December), and 2006 (between September and December), prior to the birth control program, and were used to characterize the canine and feline populations. The final study was performed in 2008 (between June and November), eighteen months after the birth control strategy had been implemented. Every household of the study area was visited in three occasions and a questionnaire regarding household and animal (sex, age and species) identification was administered. In the household identification form, questions on number of animals, whether household has been already registered in the database in a previous survey, and about what has happened to the animals (whether they were still in the house, disappeared, ran away, were abandoned or died) were administered.

The cross-sectional studies were performed using structured forms based on the following guidelines: World Health Organization Guidelines for Dog Rabies Control (WHO 1987), Guidelines for Dog Population Management (WHO \& WSPA 1990) and World Organization for Animal Health (OIE 2008). Workers from the public health care facility, which provides primary care for the community, and hired interviewers were trained to carry out the interviews.

Turnover of dog and cat populations refers to the modification of these populations during a certain time, being influenced by: birth rates, mortality and abandonment; and emigration (donation or sale of the animal to another region, mobility of families with animals) and immigration (acquisition of the animal from another region, mobility of families with pets). Turnover rate is calculated based on census data, i.e., new animals and animals already counted in previous censuses in the same area.

SPSS 9.0 software was used to perform the statistical analysis. To calculate the mean life expectancy at birth and the survival probability for each year for males and females, a vertical life table was constructed (Pianka 1994). The following equation proposed by Michod \& Anderson (1980) was used to construct the life tables for males and females:

$$
l_{i}=\frac{1_{1} N_{i}(t) \lambda^{i-1}}{N_{1}(t)} \quad(i=2,3, \cdots, n-1),
$$

where $l_{i}$ is probability of the newborn surviving until reaching interval $i, l_{1}$ is the probability of the newborn surviving until reaching interval $1, \mathrm{~N}_{1}$ represents the population size in interval 1 , $\mathrm{N}_{\mathrm{i}}$ represents the population size in interval $\mathrm{i}$, t represents the period of time and $\lambda$ represents the finite growth rate of the population, which is obtained by:

$$
\lambda=\sum_{i=1}^{n} \frac{1_{1} N_{i}(t) m_{i}}{N_{1}(t)}
$$

where $\mathrm{m}_{\mathrm{i}}$ is the number per capita of births that occurred among individuals aged between $i$ and $i+1.11$

For each sex, one exponential curve was fitted, which provided an estimate of the instantaneous mortality rate for males and females.

The mean life expectancy at birth, $\mathrm{e}_{0}$, was estimated based on the adjustment calculated using the following equation:

$$
e_{0}=\frac{\int_{0}^{L} x A e^{-\mu x} d x}{\int_{0}^{L} A e^{-\mu x} d x},
$$


where $1_{\mathrm{x}}=A \mathrm{e}^{-\mu \mathrm{x}}$ represents the exponential equation fitted to the data for the proportion surviving to age $\mathrm{x}$ for males and females, $\mathrm{A}$ is the fitted proportion of surviving newborns and $\mathrm{L}=18$ years is the maximum age observed for dogs.

The canine (feline) birth rate was calculated as the number of puppies (kittens) born in the last 12 months divided by the total number of dogs (cats) in the population.

The census results were used to characterize the animal population, construct the age pyramids and compare demographic data with the census following the intervention. The terms "existing animals" and "new animals" were applied to animals registered in a previous census and in the current census respectively.

We compared the proportion of dogs (and also cats) below 3 years of age between 2006 and 2008 using the Pearson's chi-squared test with a significance level of 0.05 .

The research was conducted within the ethical standards and approved by an ethics committee.

\section{RESULTS}

Between 2,144 and 3,190 dogs and 360 and 1,077 cats were registered in each census. The canine population increased from 2005 to 2006 and decreased from 2006 to 2008, with $11.7 \%$ reduction in the canine population in 2008 . The feline population increased at each subsequent census (Table 1).

"New animals", representing recently registered animals, that is, animals which have appeared since the last census was conducted, accounted for $41.9 \%$ of animals in 2006 (12 months after the 2005 census) and $51.3 \%$ of animals in 2008 (18 months after the 2006 census). Only 43\% of the dog population in 2008 represented animals also included in the previous census, so more than half of the population represented recently introduced animals in the area (Fig.1).

For the cats, "new animals" accounted for $64.18 \%$ in 2006 and $83.38 \%$ in 2008 . Only $30.4 \%$ of the cats in 2008 were animals already counted in previous censuses, which means that almost $70 \%$ of the cat population were newly-included animals in the area (Fig.1).

In 2006 and 2008, animals aged 1 year or under represented $39.9 \%(n=1,250)$ and $42,35 \%(n=1,121)$ of the canine population respectively. There was an increase of $3.89 \%$ of young dogs between 2005 and 2006 (12 months) and of $2.65 \%$ between 2006 and 2008 (18 months), after the intervention. Animals younger than 3 years old accounted for $64.7 \%(n=2,025)$ of the population in 2006 and $67,4 \%(n=1,715)$ in 2008 . For the cats, $73.8 \%(n=426)$ were 1 year of age or under in 2006 and $76.2 \%(n=785)$ (Table 2 and 3$)$.

The pyramidal shape with a wide base and an upper half that is less than half the base indicates a high mortality rate for juvenile animals aged one year or under which was more pronounced for female cats, indicating a low proportion of individuals surviving up to older ages (Fig.2). Observing
Fig.2, we notice, on the one hand, that the number of cats in the age intervals below 3 years increased from 484 in 2006 to 922 in 2008. A statistically significant difference $(\mathrm{p}=0.0014)$ was observed between the proportion of cats below 3 years of age in 2006 (83.9\%) and in 2008 (89.5\%). On the other hand, the number of dogs below 3 years of age decreased from 1683 in 2006 to 1437 in 2008 . However, no statistical difference in the proportion of dogs below 3 years was observed between 2006 and 2008 ( $p>0.05$ ).

Despite the annual spans, 12 months for 2016, the mean age was analyzed of this year. The mean age in 2006 was 3.36 years to the dogs and 1.66 years to the cats. From the vertical life table (Table 4), the dog mean life expectancy at birth was estimated to be 3.9 years for males and 5.9 years for females.

The instantaneous mortality rate $\left( \pm\right.$ SD) was $0.245 \pm 0.022$ year $^{-1}$ for males and $0.126 \pm 0.014$ year $^{-1}$ for females. Figure 3 shows
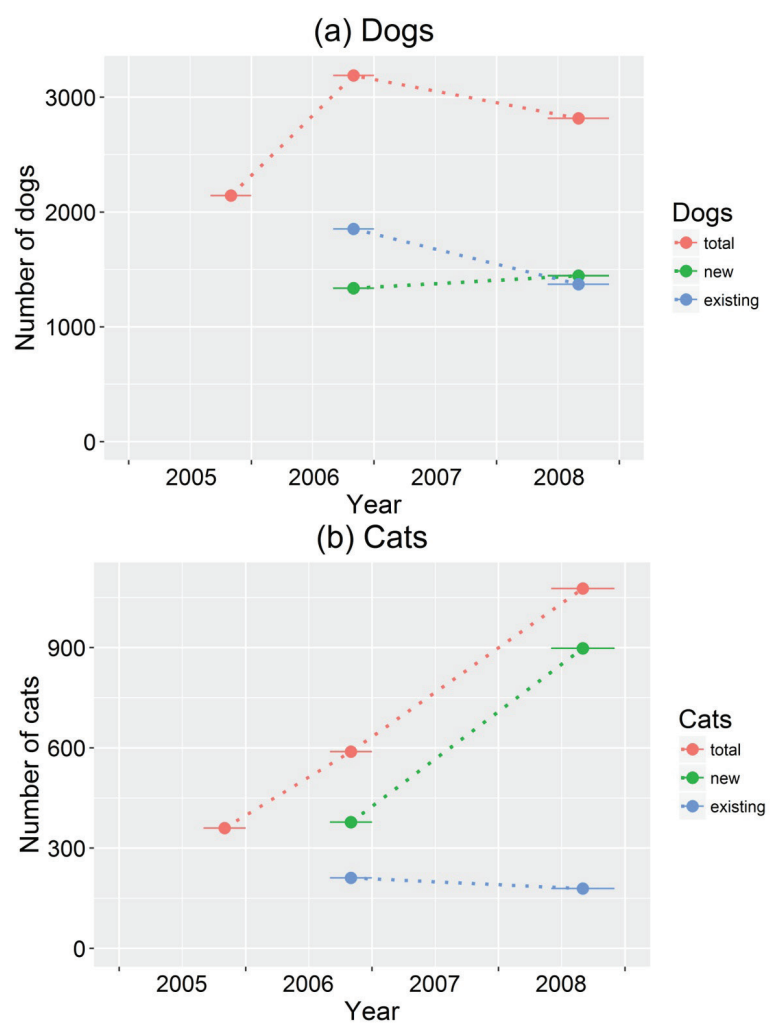

Fig.1. (a) Number of total dogs and (b) cats in 2005, 2006 and 2008, and new and existing dogs and cats in 2006 and 2008. The horizontal bars described the time intervals of performed surveys.

Table 1. Dog and cat registrations by type and census year

\begin{tabular}{|c|c|c|c|c|c|c|c|c|c|c|c|c|}
\hline & \multicolumn{12}{|c|}{ Census year } \\
\hline & \multicolumn{4}{|c|}{2005} & \multicolumn{4}{|c|}{2006} & \multicolumn{4}{|c|}{2008} \\
\hline & \multicolumn{2}{|c|}{ Dogs } & \multicolumn{2}{|c|}{ Cats } & \multicolumn{2}{|c|}{ Dogs } & \multicolumn{2}{|c|}{ Cats } & \multicolumn{2}{|c|}{ Dogs } & \multicolumn{2}{|c|}{ Cats } \\
\hline & $\mathrm{n}$ & $\%$ & $\mathrm{n}$ & $\%$ & $\mathrm{n}$ & $\%$ & $\mathrm{n}$ & $\%$ & $\mathrm{n}$ & $\%$ & $\mathrm{n}$ & $\%$ \\
\hline New & 2,144 & 100.00 & 360 & 100.00 & 1,337 & 41.91 & 378 & 64.18 & 1,445 & 51.31 & 898 & 83.38 \\
\hline Existing & 0 & 0.00 & 0 & 0.00 & 1,853 & 58.09 & 211 & 35.82 & 1,371 & 48.69 & 179 & 16.62 \\
\hline TOTAL & 2,144 & 100 & 360 & 100 & 3,190 & 100 & 589 & 100 & 2,816 & 100 & 1077 & 100 \\
\hline
\end{tabular}


Table 2. Age of dogs and cats by type and sex of 2006 census

\begin{tabular}{|c|c|c|c|c|c|c|c|c|c|c|c|c|}
\hline \multirow{4}{*}{$\begin{array}{l}\text { Age range } \\
\text { (years) }\end{array}$} & \multicolumn{12}{|c|}{ Species } \\
\hline & \multicolumn{6}{|c|}{ Dogs } & \multicolumn{6}{|c|}{ Cats } \\
\hline & \multicolumn{2}{|c|}{ Male } & \multicolumn{2}{|c|}{ Female } & \multicolumn{2}{|c|}{ Total } & \multicolumn{2}{|c|}{ Male } & \multicolumn{2}{|c|}{ Female } & \multicolumn{2}{|c|}{ Total } \\
\hline & $\mathrm{n}$ & $\%$ & $\mathrm{n}$ & $\%$ & $\mathrm{n}$ & $\%$ & $\mathrm{n}$ & $\%$ & $\mathrm{n}$ & $\%$ & $\mathrm{n}$ & $\%$ \\
\hline$\leq 1$ & 671 & 37.17 & 579 & 43.63 & 1250 & 39.91 & 199 & 76.54 & 227 & 71.61 & 426 & 73.83 \\
\hline$>1$ to $\leq 3$ & 447 & 24.76 & 328 & 24.72 & 775 & 24.74 & 42 & 16.15 & 51 & 16.09 & 93 & 16.12 \\
\hline$>3$ to $\leq 5$ & 264 & 14.63 & 202 & 15.22 & 466 & 14.88 & 9 & 3.46 & 19 & 5.99 & 28 & 4.85 \\
\hline$>5$ to $\leq 7$ & 163 & 9.03 & 90 & 6.78 & 253 & 8.08 & 6 & 2.31 & 10 & 3.15 & 16 & 2.77 \\
\hline$>7$ to $\leq 9$ & 113 & 6.26 & 55 & 4.14 & 168 & 5.36 & 3 & 1.15 & 7 & 2.21 & 10 & 1.73 \\
\hline$>9$ to $\leq 11$ & 91 & 5.04 & 43 & 3.24 & 134 & 4.28 & 1 & 0.38 & 1 & 0.32 & 2 & 0.35 \\
\hline$\geq 12$ & 56 & 3.10 & 30 & 2.26 & 86 & 2.75 & 0 & 0.00 & 2 & 0.63 & 2 & 0.35 \\
\hline TOTAL & 1805 & 100.00 & 1327 & 100.00 & 3132 & 100.00 & 260 & 100.00 & 317 & 100.00 & 577 & 100.00 \\
\hline
\end{tabular}

Table 3. Age of dogs and cats by type and sex of 2008 census

\begin{tabular}{|c|c|c|c|c|c|c|c|c|c|c|c|c|}
\hline \multirow{4}{*}{$\begin{array}{l}\text { Age range } \\
\text { (years) }\end{array}$} & \multicolumn{12}{|c|}{ Species } \\
\hline & \multicolumn{6}{|c|}{ Dogs } & \multicolumn{6}{|c|}{ Cats } \\
\hline & \multicolumn{2}{|c|}{ Male } & \multicolumn{2}{|c|}{ Female } & \multicolumn{2}{|c|}{ Total } & \multicolumn{2}{|c|}{ Male } & \multicolumn{2}{|c|}{ Female } & \multicolumn{2}{|c|}{ Total } \\
\hline & $\mathrm{n}$ & $\%$ & $\mathrm{n}$ & $\%$ & $\mathrm{n}$ & $\%$ & $\mathrm{n}$ & $\%$ & $\mathrm{n}$ & $\%$ & $\mathrm{n}$ & $\%$ \\
\hline$\leq 1$ & 654 & 42.83 & 467 & 41.70 & 1121 & 42.35 & 394 & 79.92 & 391 & 72.68 & 785 & 76.21 \\
\hline$>1$ to $\leq 3$ & 340 & 22.27 & 254 & 22.68 & 594 & 22.44 & 78 & 15.82 & 110 & 20.45 & 188 & 18.25 \\
\hline$>3$ to $\leq 5$ & 202 & 13.23 & 178 & 15.89 & 380 & 14.36 & 13 & 2.64 & 14 & 2.60 & 27 & 2.62 \\
\hline$>5$ to $\leq 7$ & 124 & 8.12 & 107 & 9.55 & 231 & 8.73 & 7 & 1.42 & 14 & 2.60 & 21 & 2.04 \\
\hline$>7$ to $\leq 9$ & 102 & 6.68 & 49 & 4.38 & 151 & 5.70 & 0 & 0.00 & 5 & 0.93 & 5 & 0.49 \\
\hline$>9$ to $\leq 11$ & 57 & 3.73 & 32 & 2.86 & 89 & 3.36 & 0 & 0.00 & 2 & 0.37 & 2 & 0.19 \\
\hline$\geq 12$ & 48 & 3.14 & 33 & 2.95 & 81 & 3.06 & 0 & 0.00 & 2 & 0.37 & 2 & 0.19 \\
\hline TOTAL & 1527 & 100.00 & 1120 & 100.00 & 2647 & 100.00 & 492 & 99.80 & 538 & 100.00 & 1030 & 100.00 \\
\hline
\end{tabular}

Table 4. Survival table for dogs, 2006 census

\begin{tabular}{|c|c|c|c|c|c|c|}
\hline \multirow{2}{*}{ Age (years) } & \multicolumn{2}{|c|}{ Sex } & \multicolumn{2}{|c|}{$m_{x}$} & \multicolumn{2}{|c|}{$l_{x}$} \\
\hline & Female & Male & Female & Male & Female & Male \\
\hline 0 & 382 & 452 & 0.0000 & 0.0000 & 0.8748 & 0.8748 \\
\hline 1 & 197 & 219 & 0.3959 & 0.3562 & 0.5356 & 0.4253 \\
\hline 2 & 173 & 260 & 0.6243 & 0.4154 & 0.5585 & 0.5067 \\
\hline 3 & 155 & 188 & 0.6355 & 0.5239 & 0.5941 & 0.3676 \\
\hline 4 & 117 & 136 & 0.7479 & 0.6434 & 0.5325 & 0.2669 \\
\hline 5 & 85 & 128 & 0.4882 & 0.3242 & 0.4593 & 0.2520 \\
\hline 6 & 59 & 87 & 0.5508 & 0.3736 & 0.3785 & 0.1719 \\
\hline 7 & 31 & 76 & 0.9032 & 0.3684 & 0.2362 & 0.1507 \\
\hline 8 & 40 & 66 & 0.3375 & 0.2045 & 0.3618 & 0.1313 \\
\hline 9 & 15 & 47 & 0.2333 & 0.0745 & 0.1611 & 0.0938 \\
\hline 10 & 32 & 74 & 0.5313 & 0.2297 & 0.4081 & 0.1482 \\
\hline 11 & 11 & 17 & 0.2273 & 0.1471 & 0.1665 & 0.0342 \\
\hline 12 & 13 & 23 & 0.2308 & 0.1304 & 0.2337 & 0.0464 \\
\hline 13 & 5 & 14 & 0.0000 & 0.0000 & 0.1067 & 0.0283 \\
\hline 14 & 7 & 8 & 0.4286 & 0.3750 & 0.1774 & 0.0162 \\
\hline 15 & 2 & 9 & 0.0000 & 0.2222 & 0.0602 & 0.0183 \\
\hline 16 & 2 & 0 & 0.0000 & 0.0000 & 0.0715 & 0.0000 \\
\hline 17 & 0 & 1 & 0.0000 & 0.0000 & 0.0000 & 0.0021 \\
\hline 18 & 1 & 0 & 0.0000 & 0.0000 & 0.0504 & 0.0000 \\
\hline
\end{tabular}

the survival probabilities $\left(1_{\mathrm{x}}\right)$ for males and females and their respective exponential curves. Adjusted survival curves for males and females were calculated using the respective following equations: $1_{x}=0.768 \mathrm{e}^{-0.245 \mathrm{x}}\left(\mathrm{R}^{2}=0.93, \mathrm{p}<0.001\right)$ and $1_{x}=0.785 \mathrm{e}^{-0.126 \mathrm{x}}\left(\mathrm{R}^{2}=0.87, \mathrm{p}<0.001\right)$.

The variation in the male:female ratio for dogs in 2005 and 2008 was $1.55: 1$ and 1.35:1 respectively, whereas that in the feline population was 1.22:1 in 2006 and 1.1:1 in 2008.

As for spaying or neutering, the frequency increased from $3.16 \%(\mathrm{n}=41)$ in 2005 to $15.4 \%(\mathrm{n}=228)$ in 2008 for neutered male dogs, and from $9.4 \%(n=79)$ in 2005 to $30.9 \%(n=347)$ in 2008 for spayed female dogs. Of the existing female dogs, $42.1 \%(n=243)$ were spayed in 2008. The canine birth rates 

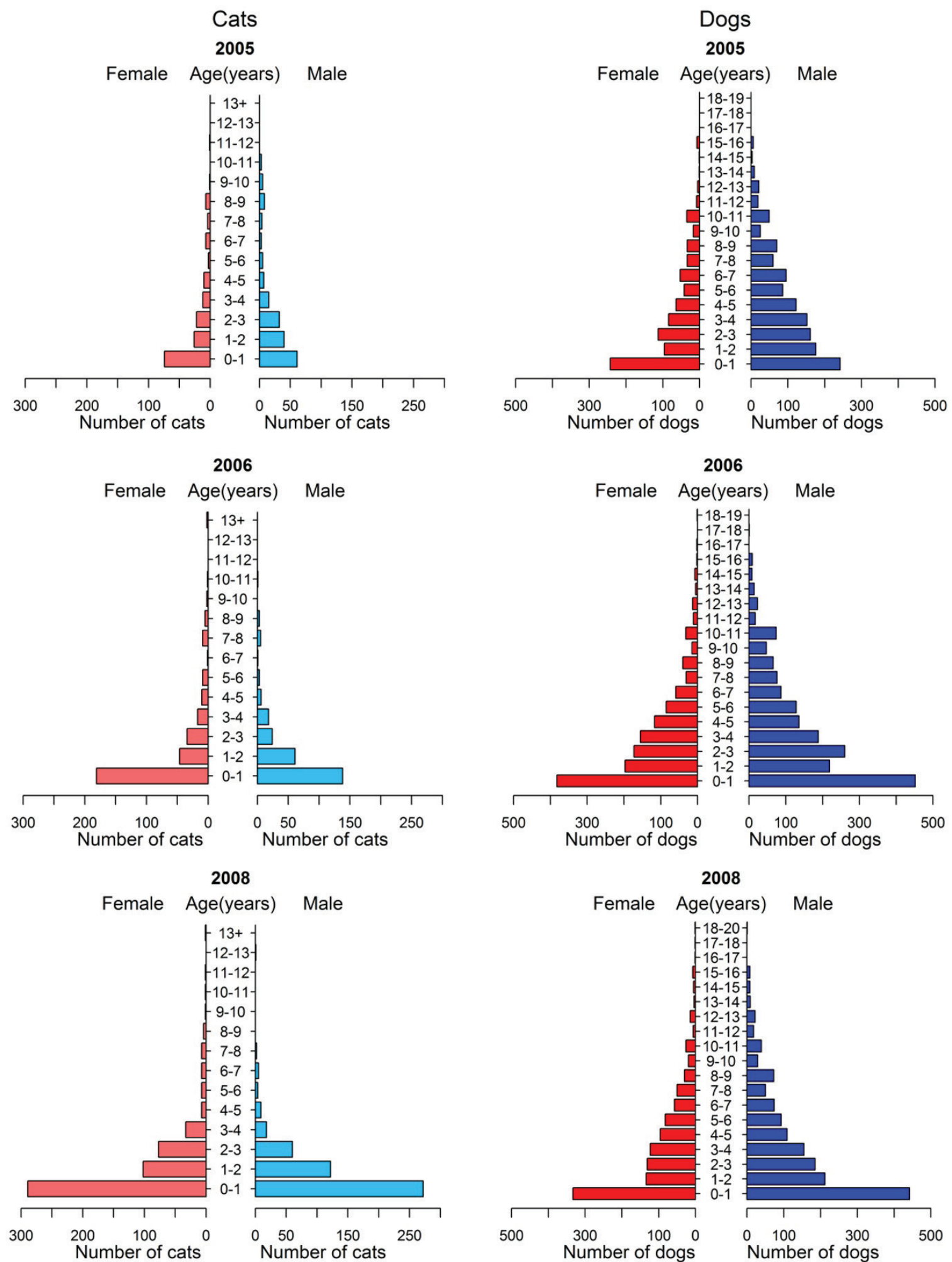

Fig.2. Age pyramids of feline and canine populations in 2005, 2006 and 2008.

were $41.8 \%$ per year in 2005 and $33.5 \%$ per year in 2008, i.e., an $8.3 \%$ decrease.

In cats, the frequency of neutered male cats increased from $7.1 \%(n=13)$ in 2005 to $24.2 \%(n=110)$ in 2008 , and the frequency of spayed female cats increased from $10.2 \%(n=17)$ in 2005 to $32.2 \%$ ( $\mathrm{n}=167)$ in 2008. Of the existing female cats, $67.6 \%(n=71)$ were spayed in 2008. The feline birth rates were $56.6 \%$ per year in 2005 and $38.1 \%$ per year in 2008, i.e., an $18.5 \%$ decrease. 

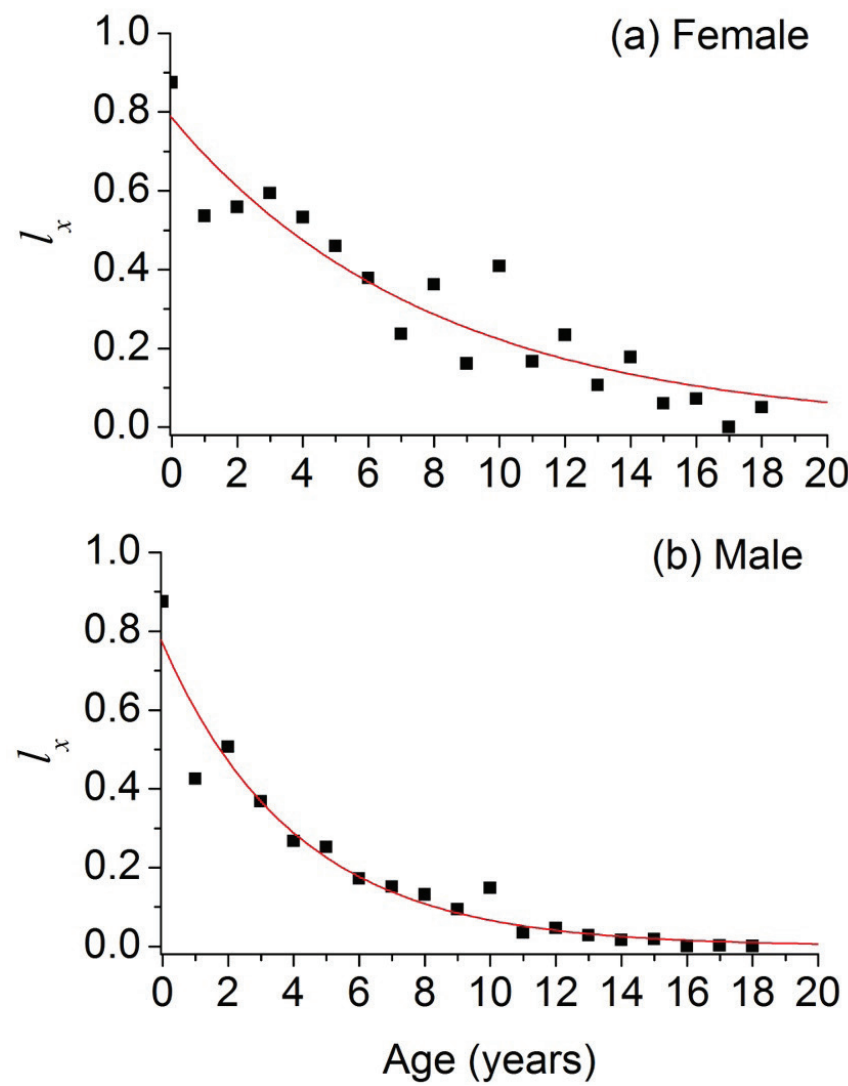

Fig.3. Survival probability and exponential curve for (a) female and (b) male dogs. 2006 census.

\section{DISCUSSION}

The increase in the canine population in 2006 may reflect the lack of reproductive control and the increase in the human population at this location, given that animal demographics are affected by human demographics (Garcia et al. 2012, WHO \& WSPA 1990). Regarding the human demographics from 2000 to 2010, the annual human population growth rate in the region was 2.46\% (São Paulo 2010). The 11.7\% reduction in the canine population in 2008 may have been the result of the birth control strategy implementation, or a cultural change on local carrying capacity due to population management and responsible guardianship, as previously shown (Baquero et al. 2016).

This was not observed in the feline population, which increased by $82.9 \%$ from 2006 to 2008 . Providing spay or neuter surgery may have encouraged families in the study area to acquire new cats or to retain their existing cats. On the other hand, cat population is increasing throughout the city.

The population turnover was characterized for the proportion between "existing animals" and recently registered animals ("new animals") in the area. In 2008, more than $50 \%$ of dog and cat population was recently introduced in the area, particularly in the feline population, which reached $83.4 \%$ of new animals. Despite the different time spans, 12 months for 2006 and 18 months for 2008, the turnover was considered high to the population. This turnover is affected by birth rates, mortality rates and animal acquisition rates, but by family mobility in the region (the immigration and emigration of families with their pets) too. Whereas most emerging diseases are zoonosis, a high animal turnover represents a risk to the community health because the health status of these animals is unknown.

In 2006, the frequency of dogs aged one year or under was $39.9 \%$. There was an increase of $3.89 \%$ of young dogs between 2005 and 2006 (12 months) and of 2.65\% between 2006 and 2008 (18 months), after the intervention. Many studies have reported a larger frequency of young animals in canine populations: $50 \%$ reported in Kenya (Kitala et al. 2001), 57\% in Nigeria (Oboegbulem \& Nwakonobi 1989). In Sri Lanka (WHO 1988), USA (Griffiths \& Brenner 1977), Ecuador (WHO 1988), Chile (Rodolfo Martin et al. 1977), and in the Brazilian city of Araçatuba (Nunes et al. 1997), lower frequencies were found.

The frequency of $73.8 \%$ for cats aged one year or under observed in this study was higher than in the USA (43.9\%) (Griffiths \& Brenner 1977). Agostini et al. (1986) reported, in Buenos Aires, a frequency of $64.9 \%$ for the feline population between 0 and 2 years of age.

For both species, the age pyramids have a wide base, which is consistent with high fertility and fecundity rates, and high mortality rate for juvenile animals aged one year or under. As a result, only a low proportion of individuals has survived to adulthood, and an even lower proportion survived to an older age. The high dogs and cats reproductive potentials, the low levels of responsible ownership and the lack of public policies regarding population balance contribute with the high birth rates and mortality rates, low mean age and high rates of turnover (WHO \& WSPA 1990). Consequently, it is difficult to control diseases that bear a zoonotic potential and to achieve herd immunity which may prevent disease spreading. These factors impacted negatively on rabies and leishmaniosis control, for example. Animals younger than 1 year old may have lacked the opportunity to be vaccinated at the campaigns against rabies, and those that were vaccinated may not have survived long enough, hence with little contribution to the herd immunity.

The presence of juvenile animal populations with a large number of susceptible animals poses a public health risk. Strategies to decrease the birth rate and increase the average lifespan of the animals will assist in promoting public health and animal welfare.

The mean age of the dogs was 3.36 years, greater than that found in Ecuador (Beran \& Frith 1988) and similar to that reported in other countries in Latin America (Larrieu et al. 1992). For the feline population, the mean age was 1.66 years, lower than that found in Champaign, Illinois (Griffiths \& Brenner 1977), Saint Joseph County, Indiana (Patronek et al. 1997) and Las Vegas, Nevada (Nassar et al. 1984), all in the USA. Regarding life expectancy for male and female dogs (3.9 years and 5.9 years respectively), the higher mortality rates of males are likely associated with the behavior of these animals.

In Latin America, studies have found from 1.12 to 3.29 male dogs for each female (Rodolfo Martin et al. 1977, Rangel et al. 1981, Agostini et al. 1986, Fernández 1986, Larrieu et al. 1990, Nunes et al. 1997, Gomes et al. 2003, Molento et al. 2007). The presence of more male than female dogs may have indicated a preference for males, which may have been consistent with previous studies in Chile (Rodolfo Martin et al. 1977), Mexico (Rangel et al. 1981), Argentina (Agostini et al. 
1986, Larrieu et al. 1990) and an overall of Latin America (Garcia et al. 2012). In USA, studies have found more male than female dogs as well (Schneider \& Vaida 1975, Griffiths \& Brenner 1977), either elimination of female puppies or abandonment of female puppies and selective adoption of males from the street could explain this. In Kenya, Kitala et al. (2001) reported that the preference for male dogs was related to the belief that they are better guard dogs and hunters. Additionally, a lower mortality rate was observed for males. It is believed that the lower mortality rates are a function of the better selective care that males receive compared with females.

Age and sex ratios have implications for population turnover and survival rates and for estimating the costs of disease and animal control. The male:female ratio for dogs and cats was reduced following birth control intervention. Although no owner perception was assessed on this matter, ratio changing may have reflected a less avoidance to owning female pets since spaying may have prevented major problems such as unwanted heat and birth.

The canine and feline birth rates were $41.8 \%$ and $56.6 \%$ respectively in 2005 and $33.5 \%$ and $38.1 \%$ respectively in 2008 . That is, decrease in birth rate was observed in both pet species, with $8.3 \%$ in canine and $18.5 \%$ in feline population. Such decreases may be related to the birth control services provided in the project. The canine birth rates were lower than those reported by Larrieu et al. (1990) and higher than those reported by Agostini et al. (1986) in Buenos Aires, Argentina.

Prior to the birth control program, the frequency of neutering male dogs was lower than that reported by Kitala et al. (2001) in Kenya, and the frequency of spaying female dogs was 19\% higher. The frequency of spayed dogs and cats in the present study was lower than the frequency found in the USA (Schneider \& Vaida 1975, Patronek et al. 1997) and Argentina (Larrieu et al. 1990); and higher than the results reported for São Paulo, Brazil (Gomes et al. 2003). After birth control actions were taken, the frequency of spayed or neutered animals doubled and were higher than the frequencies previously assessed in other city areas such as Jardim Paraná, Brasilândia (Gomes et al. 2003) and a comprehensive animal population study throughout the city (Canatto et al. 2012).

\section{CONCLUSIONS}

Canine and feline populations were young and characterized by high birth and high mortality rates for juveniles less than 1 year of age. Mean age of cats was lower than that of dogs. Cats also had a higher animal population turnover. Male:female ratio for dogs and cats had a reduction following birth control intervention.

There was an increase in the number of spayed or neutered animals in the respective canine and feline populations and a consequent decrease in the birth rates following birth control intervention. In addition, a reduction in population size was observed following intervention in dogs but not in cats.

A major limitation of the present study was that only the owned (domiciled) pet population has been assessed throughout the study. Further studies should also focus on semi-domiciled and stray dogs and feral cats, since a recent study of our group has shown that such population may play an important role on pet population dynamics and veterinary public policies.
Acknowledgements.- To Education and Animal Control Technical Institute (ITEC) and World Animal Protection (WPA); and to Brazilian Federal Agency for Support and Evaluation of Graduate Education (CAPES-PE/2005) and São Paulo Research Foundation (FAPESP-06/52686-0) for funding.

\section{REFERENCES}

Agostini A., Franco A., Sommerfelt I., Lema J.A. \& Kistermann J.C. 1986. Aspectos de la demografia canina y felina en el partido de General San Marín, Buenos Aires. Revta Med. Vet. 67(1):32-37.

Amaku M., Dias R.A. \& Ferreira F. 2009. Dinâmica populacional canina: potenciais efeitos de campanhas de esterilização. Revta Panam. Salud Publica 25(4):300-304. http://dx.doi.org/10.1590/S1020-49892009000400003. PMid:19531317.

Baquero O.S., Akamine L.A., Amaku M. \& Ferreira F. 2016. Defining priorities for dog population management through mathematical modeling. Prev. Vet. Med.123:121-127. http://dx.doi.org/10.1016/j.prevetmed.2015.11.009. PMid:26652574.

Beran G.W. \& Frith M. 1988. Domestic animal rabies control: an overview. Rev. Infect. Dis. 10(Suppl.4):S672-S677. http://dx.doi.org/10.1093/clinids/10. Supplement_4.S672. PMid:3206079.

Canatto B.D., Silva E.A., Bernardi F., Mendes M.C.N.C., Paranhos N.T. \& Dias R.A. 2012. Caracterização das populações de cães e gatos supervisionados do município de São Paulo. Arq. Bras. Med. Vet. Zootec. 64(6):1515-1523. http://dx.doi.org/10.1590/S0102-09352012000600017.

Dias R.A., Garcia R.C., Silva D.F., Amaku M., Ferreira Neto J.S. \& Ferreira F. 2004 Estimativa de populações canina e felina domiciliadas em zona urbana do Estado de São Paulo. Revta Saude Publica 38(4):565-570. http://dx.doi org/10.1590/S0034-89102004000400013. PMid:15311298.

Fernández F. 1986. Población canina: su cinética e influencia sobre la enzootia rábica. Vet. Argent. 3(22):176-181.

Garcia R.C.M. 2009. Estudo da dinâmica populacional canina e felina e avaliação de ações para o equilíbrio dessas populações em área da cidade de São Paulo, SP, Brasil. Tese de Doutorado, Departamento de Medicina Veterinária Preventiva e Saúde Animal, Universidade de São Paulo, SP 265p. http://dx.doi.org/10.11606/T.10.2009.tde-18012010-154127.

Garcia R.C.M., Calderón N. \& Ferreira F. 2012. Consolidação de diretrizes internacionais de manejo de populações caninas em áreas urbanas e proposta de indicadores para seu gerenciamento. Revta Panam. Salud Publica 32(2):140-144. http://dx.doi.org/10.1590/S1020-49892012000800008. PMid:23099875.

Gomes L.H., Almeida M.F., Paranhos N.T., Garcia R.C.M., Nunes V.F.P. \& Cardoso S.M.S. 2003. Avaliação de riscos à saúde e intervenção local associadas ao convívio com cães e gatos, Jardim Paraná, Brasilândia, São Paulo. Vet. Zootec. 6(1-3):83-94.

Griffiths A.O. \& Brenner A. 1977. Survey of cat and dog ownership in Champaign County, Illinois. J. Am. Vet. Med. Assoc. 170(11):1333-1340. PMid:863781.

ICAM 2007. Human and dog population management guidance. International Companion Animal Management Coalition. Available at <http://www. icam-coalition.org/downloads/Humane_Dog_Population_Management_ Guidance_English.pdf>

Kitala P., McDermott J., Kyule M., Gathuma J., Perry B. \& Wandeler A. 2001 Dog ecology and demography information to support the planning of rabies control in Machakos District, Kenia. Acta Trop. 78(3):217-230. http://dx.doi.org/10.1016/S0001-706X(01)00082-1. PMid:11311185.

Larrieu E., Alavarez T., Cavagion L. \& Herrasti A. 1992. Dinámica de la población canina de General Pico, Argentina en el periodo 1986/1990. Vet. Argent. 9(88):536-542.

Larrieu E., Alvarez T., Cavagión L. \& Herrasti A. 1990. Aporte al estudio de la dinámica de las poblaciones caninas. Vet. Argent. 7(64):242-247. 
Michod R.E. \& Anderson W.W. 1980. On calculating demographic parameters from age frequency data. Ecology 61(2):265-269. http://dx.doi. org/10.2307/1935184.

Molento C.F.M., Lago E. \& Bond G.B. 2007. Dog and cat population control in ten rural villages, Paraná, Brazil. Arch. Vet. Sci. 12(3):43-50.

Nassar R., Mosier J.E. \& Williams L.W. 1984. Study on the feline and canine populations in the greater Las Vegas area. Am. J. Vet. Res. 45(2):282-287. PMid:6711951.

Nunes C.M., Martines D.A., Fikaris S. \& Queiróz L.H. 1997. Avaliação da população canina da zona urbana do Município de Araçatuba, São Paulo, SP, Brasil. Revta Saude Publica 31(3):308-309. http://dx.doi.org/10.1590/ S0034-89101997000300013. PMid:9515268.

Oboegbulem S.I. \& Nwakonobi I.E. 1989. Population density and ecology of dogs in Nigeria: a pilot study. Rev. Sci. Tech. 8(3):733-745. http://dx.doi. org/10.20506/rst.8.3.426.

OIE 2008. Stray dog population control. Organização Internacional de Epizootias: Terrestrial Animal Health Code, Paris. Available at <http:// www.oie.int/fileadmin/Home/eng/Health_standards/tahc/2010/ en_chapitre_1.7.7.htm>.

Patronek G.J., Beck A.M. \& Glickman L. 1997. Dynamics of dog and cat populations in a community. J. Am. Vet. Med. Assoc. 210(5):637-642. PMid:9054991.

Pianka E.R. 1994. Vital statistics of populations: demography, p.144-161. In: Ibid. (Ed.), Evolutionary Ecology. 5th ed. Harper Collins College Publishers, New York.
Rangel C.F., Lara J.C. \& De Aluja A.S. 1981. The canine population of Mexico City: an estimative study. Anim. Regul. Study 3:281-290.

Rodolfo Martin M., Francisco Marin L.B. \& Miguel Rivera M. 1977. Estudio demográfico de La poblacion canina em localidades urbanas menores de 8.500 habitantes de La província de Valdivia. Arch. Med. Vet. 9(1):29-35.

São Paulo 2010. População Recenseada e Taxas de Crescimento. Município de São Paulo, Regiões e Distritos Municipais 1980, 1991, 2000 e 2010. Prefeitura de São Paulo. Disponível em < http://infocidade.prefeitura.sp.gov. br/htmls/7_populacao_recenseada_e_taxas_de_crescime_1980_10747. html>

Schneider R. \& Vaida M.M.L. 1975. Survey of canine and feline populations: Alameda and Contra Costa Counties, California, 1970. J. Am. Vet. Med. Assoc. 166(5):481-486. PMid:1112753.

WHO \& WSPA 1990. Guidelines for dog population management. World Health Organization and World Society for the Protection of Animals, Geneva.

WHO 1984. Seventh Report, WHO Technical Report Series n.709, WHO Expert Committee on Rabies. World Health Organization, Geneve.

WHO 1987. Guidelines for dog rabies control. World Health Organization, Geneva.

WHO 1988. Report of WHO Consultation on dog ecology studies related to rabies control. World Health Organization, Geneve. 